\title{
PENGARUH MASUKAN ENERGI JUMLAH PANAS (MEJP) DAN DOSIS PUPUK FOSFOR TERHADAP PERTUMBUHAN DAN HASIL TANAMAN KEDELAI (Glycine max L. Merril)
}

\author{
EFFECTS OF THERMAL ENERGY INPUT AMOUNT AND PHOSPHORUS \\ FERTILIZER DOSAGE ON SOYBEAN PLANT CROP (Glycine max L. Merril)
}

\author{
Ningsi Riani Kurnia $\left.{ }^{1}\right)^{*}$, Yawahar Jon $^{2}$ ), Fitriani Dwi ${ }^{2}$ ), Suryadi ${ }^{2}$ ), Fiana Podesta ${ }^{2}$ ) \\ Jurusan Agroteknologi Fakultas Pertanian, Universitas Muhammadiyah Bengkulu, Jl. Bali, PO Box \\ 118, Telp. 0736-22765, fx. 26161, Website: www.umb,ac.id. Email: dwifitriani@umb.ac.id, \\ Bengkulu 38119
}

\begin{abstract}
This study aims to determine the effect of heat energy input with a dose of phosphorus fertilizer on soybean (Glycine max L.Merril) crops. This research was conducted in July untill October 2019 on J1. Danau Raya No.59, Panorama, Singaran Pati, Bengkulu City of Bengkulu province with a height of $+24 \mathrm{~m}$ above sea level. This study used a Completely Randomized Design prepared by factorial $(R A L-F)$ with two factors, where factor 1 was the input of the amount of heat energy $(E) E 1=1030-1050$ SP, E2 = 1130-1150 SP, E3 = 1230-1250 SP, E3 = 1330-1350 SP, factor 2 was the dose of phosphorus fertilizer $(\mathrm{P}) \mathrm{P} 1=75 \mathrm{~kg} / \mathrm{ha}, \mathrm{P} 2=150 \mathrm{~kg} / \mathrm{ha}, \mathrm{P} 3=225 \mathrm{~kg} / \mathrm{ha}$. Each treatment was repeated 3 times. The results of the data were analyzed using Analysis of Variance Analysis (ANOVA) was significantly different. Further testing of Duncan Multiple Range Test (DMRT) was 0.5\%. The results of the heat energy input treatment showed very significantly different variables on plant wet weight, seed weight, and showed significantly different variables on plant dry weight, and pod weight. While the energy input treatment on the amount of heat and the dose of phosphorus fertilizer interacts with the variables of plant height, number of leaves and seed weight.
\end{abstract}

Keywords: Thermal Energy Input, Dose of Phosphorus Fertilizer.

\begin{abstract}
ABSTRAK
Penelitian ini bertujuan untuk mengetahui pengaruh masukan energi jumlah panas dengan dosis pupuk fosfor terhadap hasil tanaman kedelai (Glycine max L. Merril). Penelitian ini telah laksanakan pada bulan Juli-Oktober 2019 di Jl. Danau Raya No.59, Panorama, Singaran Pati, Kota Bengkulu, Bengkulu dengan ketinggian $+24 \mathrm{~m}$ dpl. Penelitian ini menggunakan Rancangan Acak Lengkap disusun dengan factorial(RAL-F) dengan dua faktor, dimana faktor 1 adalah masukan energi jumlah panas $(\mathrm{E}) \mathrm{E} 1=1030-1050 \mathrm{SP}, \mathrm{E} 2=$ 1130-1150 SP, E3= 1230-1250 SP, E3= 1330-1350 SP. Faktor 2 adalah dosis pupuk fosfor (P) $\mathrm{P} 1=75 \mathrm{~kg} / \mathrm{ha}, \mathrm{P} 2=150 \mathrm{~kg} / \mathrm{ha}, \mathrm{P} 3=225 \mathrm{~kg} / \mathrm{ha}$ masing-masing perlakuan diulang $3 \mathrm{kali}$. Hasil data dianalisis menggunakan Analisis Sidik Ragam (ANOVA) dan apabila berbeda nyata dilakukan uji lanjut Duncan Multiple Range Test (DMRT) taraf 0,5\%. Hasil perlakuan masukan energi jumlah panas menunjukan berbeda sangat nyata terhadap peubah berat
\end{abstract}


basah tanaman, berat biji, dan menunjukan berbeda nyata terhadap peubah berat kering tanaman, berat polong. Sedangkan perlakuan masukan energi jumlah panas dan dosis pupuk fosfor terjadi interaksi pada peubah tinggi tanaman, jumlah daun dan berat biji.

Kata kunci : Masukan Energi Jumlah Panas, Dosis Pupuk Fosfor.

\section{1 . Latar Belakang}

\section{PENDAHULUAN}

Kedelai (Glycine max L. Merril) merupakan salah satu komoditas kacang-kacangan yang menjadi sumber protein nabati yang disukai oleh masyarakat Indonesia (Sari 2014). Setiap 100 gram biji kedelai mengandung $18 \%$ lemak, $35 \%$ karbohidrat, $8 \%$ air, 3,30 kalori, $35 \%$ protein dan $52,5 \%$ mineral yang sangat penting karena gizinya aman dikonsumsi. Di Indonesia itu sendiri kedelai umumnya dikonsumsi dalam bentuk olahan pangan seperti susu kedelai, tempe, tahu, dan macam-macam olahan makanan ringan lainnya ( Susanto dan Sudari, 2011).

Tanaman kedelai merupakan salah satu komoditas yang banyak dibudidayakan oleh masyarakat di Indonesia. Jumlah produksi kedelai yang dibudidayakan oleh masyarakat belum cukup untuk memenuhi permintaan pasar karena masih banyak masyarakat yang belum mengetahui tentang bagaimana cara budidaya kedelai yang benar dan baik, tanah atau lahan untuk membudidayakan tanaman kedelai sudah banyak diahli fungsikan seperti gedunggedung dan lain-lain (Dwi, 2011)

Menurut Badan Pusat Statistik (2017) produksi kedelai di Bengkulu pada tahun 2015 sebanyak 5.388 ton. Pada tahun 2016 terjadi penurunan produksi kedelai yang hanya mencapai 4.666 ton, hal ini disebabkan adanya penurunan produksi kedelai di beberapa wilayah di provinsi Bengkulu tepatnya di kabupaten Muko-Muko, Kaur, Rejang Lebong, Bengkulu Selatan dan Seluma (AntaraBengkulu.com, 
2015). Produksi kedelai di Bengkulu hanya dapat memenuhi kebutuhan pembuatan tahu dan tempe sebanyak 2.400 ton per tahun (Yusuf 2013). Untuk mencukupi kebutuhan kedelai dalam pembuatan makan dan non

makanan lainnya Bengkulu masih mengimpor kedelai dari daerah luar seperti Jawa dan Lampung.

Kebutuhan kedelai semakin meningkat dari tahun ketahun sejalan dengan pertambahan penduduk, meningkatnya pendapatan perkapitan dan meningkatnya kesadaran masyarakat terhadap makanan yang mengandung

protein nabati. Akan tetapi produksi kedelai semakin menurun setiap tahun. Produksi rata-rata kedelai di Bengkulu yang masih rendah disebabkan oleh beberapa faktor, diantaranya bercocok tanam yang kurang baik, proses fisiologis tanaman yang tidak sempurna, pemeliharaan yang tidak intensif, pemupukan yang tidak tepat serta adanya serangan hama dan penyakit (Efendi 2010).

Untuk mendapatkan hasil panen yang berkuliatas harus dilakukan pada saat yang tepat. Keterlambatan panen dapat berdampak pada penurunan kualitas dari biji kedelai. Menurut Sarawa et al. (2012) pemasakan atau pematagan kedelai merupakan faktor yang sangat penting dalam menghasilkan mutu benih. Waktu panen yang tidak tepat atau kesalahan waktu panen dapat menurunkan mutu benih Pmenggunakan metode satuan panas. Satuan panas merupakan metode untuk menentukan saat matang, metode ini juga dapat menentukan umur saat panen 
berdasarkan pendekatan klimatologi dan

agronomi. Hingga saat ini, informasi mengenai penggunaan metode tersebut pada tanaman kedelai masih sedikit, terutama dengan varietas kedelai (Sulistyowati 2015). Penerapan metode akumulasi satuan panas dapat menentukan umur panen tanaman, sehingga waktu panen lebih presisi (Sattar et al. 2015).

Energi panas (heat Unit) dapat digunukan untuk menentukan saat panen yang tepat sehingga kerusakan biji dan rasa dapat dihindari dan akan mendapatkan kualitas kacang yang baik. Berdasarkan penelitian Podesta (1997) masukan energi jumlah panas 1230-1250 SP 124125 hari sangat berpengaruh terhadap bobot biji pertanaman, sedangkan masukan energi jumlah panas 1330-1350 SP 136-138 hari mempengaruhi terhadap mutu benih dan pada masukan energi jumlah panas 1330-1350 SP 136-138 hari mempengaruhi terhadap kualitas gizi kacang kedelai.

Rendahnya produktivitas kedelai di Bengkulu di sebabkan karena penerapan teknologi oleh petani yang belum tepat. Upaya untuk meningkatkan produktivitas sebenarnya sudah banyak dilakukan seperti penggunaan varietas unggul dan berbaikan

budidaya. Salah satu teknik budidaya adalah dengan menggunakan pupuk $\mathrm{P}$ dalam jumlah yang cukup sesuai dengan lingkungan tanaman. Menurut Aksi Agraris Kanisium (2000) kedelai merupakan salah satu tanaman yang membutuhkan fosfor dalam jumlah besar. Ketersediaan fosfor merupakan faktor pembatas utama pada pertumbuhan dan produksinya. Pengguaan fosfor dimulai pada masa pembentukan polong sampai sepuluh hari sebelum biji berkembang. Secara umum fungsi fosfor dalam tanaman dapat mempercepat pertumbuhan akar semai, mempercepat serta memperkuat pertumbuhan tanaman

muda menjadi tanaman dewasa, 
mempercepat pembungaan, pemasakan buah dan biji serta dapat meningkatkan produksi (Sutedjo, 2002).

Dari uraian diatas perlu dilakukan penelitian mengenai masukan energi jumlah panas dengan dosis pupuk fosfor terhadap hasil tanaman kedelai (Glycine max L. Merril ).

\subsection{Tujuan}

1. Untuk mengetahui masukan energi jumlah panas berpengaruh nyata terhadap pertumbuhan dan hasil tanaman kedelai (Glycine max L. Merril).

2. Untuk mengetahui pupuk fosfor berpengaruh nyata terhadap pertumbuhan dan hasil tanaman kedelai (Glycine max L. Merril).

3. Untuk mengetahui pengaruh interaksi masukan energi jumlah panas dengan dosis pupuk fosfor terhadap pertumbuhan dan hasil tanaman kedelai (Glycine max L. Merril).

\subsection{Hipotesis}

1. Masukan energi jumlah panas berpengaruh nyata terhadap pertumbuhan dan hasil tanaman kedelai (Glycine max L. Merril).

2. Pupuk fosfor berpengaruh nyata terhadap pertumbuhan dan hasil tanaman kedelai (Glycine $\max$ L. Merril).

3. Interaksi masukan energi jumlah panas dengan dosis pupuk fosfor berpengaruh nyata terhadap pertumbuhan dan hasil tanaman kedelai (Glycine max L. Merril).

\section{METODOLOGI PENELITIAN}

\subsection{Tempat dan Waktu}

Penelitian ini telah laksanakan di Jl. Danau Raya No. 59, Panorama, Singaran Pati, Kota Bengkulu, Bengkulu dengan ketinggian +24 mdpl, sedangkan waktu penelitian akan dilaksanakan pada bulan Juli-Oktober 2019.

\subsection{Bahan dan Alat}

Bahan-bahan yang digunakan dalam penelitian ini adalah: benih kedelai varietas 
Dena 1 diperoleh dari balai kacang-kacangan dan umbi-umbian, Malang. Pupuk fosfor, Rhizobium, polybag, furadan dan air.

Alat-alat yang digunakan meliputi: cangkul, ember, selang, gayung, alat tulis, timbangan analitik, kamera, hansprayer, dan thermometer maksimum dan minimu serta alat ukur mistar.

\subsection{Metode Penelitian}

Penelitian ini dilaksanakan dengan menggunakan rancangan acak lengkap (RAL) disusun secara faktorial, dengan dua faktor yaitu masukan energi jumlah panas dan dosis pupuk fosfor.

Faktor pertama adalah masukan energi jumlah panas (E) yang terdiri :

$\mathrm{E} 1 \quad=1030-1050 \mathrm{SP}$

$\mathrm{E} 2 \quad=1130-1150 \mathrm{SP}$

$\mathrm{E} 3 \quad=1230-1250 \mathrm{SP}$

E3 $=1330-1350 \mathrm{SP}$

Faktor kedua adalah dosis pupuk fosfor $(\mathrm{P})$

yang terdiri dari :

$\mathrm{P} 1=75 \mathrm{~kg} / \mathrm{ha}$

$\mathrm{P} 2=150 \mathrm{~kg} / \mathrm{ha}$

$\mathrm{P} 3=225 \mathrm{~kg} / \mathrm{ha}$

Dalam penelitian ini terdapat 12

kombinasi perlakuan yang diulang sebanyak 3 kali sehingga diperoleh 36 
satuan percobaan. Setiap unit percobaan terdiri dari 3 tanaman sampel. Jika antar perlakuan masukan energi jumlah panas dan dosis pupuk fosfor memberikan pengaruh yang nyata maka dilanjutkan dengan ANOVA dan uji jarak berganda Duncan / Duncan Multiple Range Test (DMRT).

\subsection{Model RAL}

Model linier aditif untuk rancangan faktorial dua faktor dengan rancangan lingkungannya RAL (Syahni dan Nelly, 2017) sebagai berikut:

$$
Y_{\mathbf{i j k}}=\boldsymbol{\mu}+\boldsymbol{\alpha}_{\mathbf{i}}+\boldsymbol{\beta} \mathbf{j}+(\boldsymbol{\alpha} \boldsymbol{\beta}) \mathbf{i j}+\varepsilon_{\mathbf{i j k}}
$$

Keterangan :

Yijk = nilai pengamatan pada satuan

percobaan yang memperoleh perlakuan taraf ke-i dari faktor A, taraf ke-j faktor B, dan ulangan ke-k.

$\mu \quad=$ nilai tengah umum

$\alpha i \quad=$ pengaruh taraf ke-i dari faktor $\mathrm{A}$

$\beta j=$ pengaruh taraf ke-j dari faktor $B(\alpha \beta) i j=$ pengaruh interaksi dan taraf ke-i

dari faktor A dan taraf ke-j dari faktor B

$\Sigma i j k=$ pengaruh galat pada satuan

percobaan yang memperoleh perlakuan taraf ke-i dari faktor A, taraf ke-j dari faktor B, dan ulangan yang ke-k.

\subsection{Analisis data}

Tabel2. Sidik ragam rancangan acak lengkap faktorial disajikan sebagai berikut:

\begin{tabular}{llllll}
\hline SK & \multicolumn{1}{c}{ DB } & JK & KT & F-hitung & F-tabel \\
\hline A & a-1 & JKA & KTA & KTA/KTG & F $(\alpha$, db-A, db-G $)$ \\
B & b-1 & JKB & KTB & KTB/KTG & F $(\alpha$, db-B, db-G $)$ \\
AB & $(a-1)(b-1)$ & JKAB & KTAB & KTAB/KTG & F $(\alpha$, db-AB, db-G $)$ \\
Galat & ab-1(r-1) & JKG & KTG & & \\
\hline
\end{tabular}

Total abr-1 JKT

Sumber : (Syahni dan Nelly, 2017)

Keterangan :

SK : Sumber Keragaman
DB : Derajat Bebas

JK : Jumlah Kuadrat 


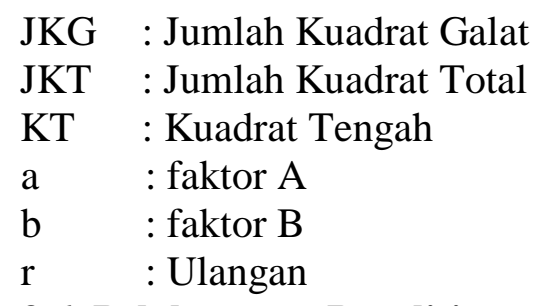

\subsection{Pelaksanaan Penelitian}

Pelaksanaan percobaan dapat dikelompokan berdasarkan tahapannya sebagai berikut :

\subsubsection{Persiapan media tanam}

Media tanam di campur dengan pupuk kandang yang bertujuan untuk menambah unsur hara nitrogen. Lakukan pengisian ke dalam polybag dengan media tanam yang sudah dipersiapkan. Sebelum dilakukan penanaman, tanah di diamkan selama lebih kurang 2 minggu.

3.6.2. Penanaman dan pemeliharaan Sebelum benih ditanam, benih terlebih dahulu diinokulum dengan rhizobium 5-7 gram/kg dan penanaman benih kedelai dilakukan dalam polybag, dengan membuat lubang tanam sedalam $2 \mathrm{~cm}$ di tengah polybag dengan jarak tanam per plot yaitu $40 \mathrm{~cm}$ x $30 \mathrm{~cm}$. Penjarangan dilakukan apabila tanaman sudah berumur 14 hari setelah tanam (Hst) dengan menyisakan 1 tanaman.

Hama dan penyakit dikendalikan dengan cara manual yaitu apabila terdapat tanaman yang terkena serangan hama dan

penyakit. Jika ada hama, hama dikumpulkan dan di musnakan dan apabila terkena serangan penyakit tanaman bisa dicabut atau dipotong bagian yang terkena serangan agar tidak menular dengan tanaman lainnya. Pengendalian dilakukan pada saat tanaman sudah berumur 3 minggu setelah tanam dengan selang 2 minggu untuk pengendalian selanjutnya dilakukan penyiraman pagi dan sore hari agar menjaga tanah tetap keadaan lembab untuk menunjang pertumbuhan kedelai.

\subsubsection{Pengaplikasian}


Penghitungan masukan energi jumlah panas dilakukan setiap hari sampai jumlah energi satuan panas sesuai dengan masing-masing perlakuan penghitungan dilakukan dengan menggunakan formula jumlah panas reduksi tinggi yaitu :

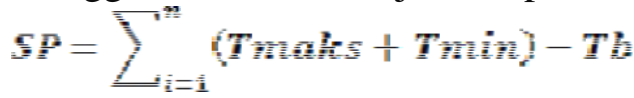

Dimana :

$\mathrm{SP} \quad=$ jumlah panas

Tmaks = suhu maksimal harian

Tmin = suhu minimal harian

$\mathrm{Tb}=$ suhu dasar tanaman kedelai $10^{\circ} \mathrm{C}$

$\eta \quad=$ jumlah hari

$\mathrm{i}=$ hari setelah tanam sampai periode perkembangan tertentu.

Pengaplikasian pupuk fosfor dilakukan dua kali pada saat awal tanam dan pada saat tanaman mulai berbunga pada umur 33 hari setelah tanam.

\subsubsection{Parameter yang diamati}

1. Tinggi tanaman (cm)

Tinggi tanaman dihitung pada saat tanaman mulai berumur 2 minggu. Caranya dengan mengukur tinggi tanaman dari permukaan tanah sampai pada daun yang muda atau titik apikal. Pada setiap tanaman diberi tanda pada supaya tidak keliruh dari mana mengukur tinggi tanaman.

\section{Jumlah daun (helai)}

Jumlah daun dihitung dari daun yang telah terbuka sempurna pada setiap tanaman dilakukan pada saat tanaman berumur 2 minggu sampai 6 minggu.

\section{Jumlah cabang}

Jumlah cabang tanaman dihitung pada setiap tanaman dilakukan pada saat tanaman berumur 2 minggu sampai 6 minggu.

\section{Berat basah tanaman (gr)}

Berat basah didapatkan dengan cara menimbang seluruh bagian tanaman dengan menggunakan timbangan analitik (Digital 
Sartorius Bp 3100p) dilakukan pada saat akhir penelitian.

\section{Berat kering tanaman (gr)}

Berat kering ditimbang ketika sudah dijemur selama 3 hari sampai berat konstan. Pengamatan dilakukan diakhir penelitian.

\section{Jumlah polong (buah)/tanaman}

Dihitung pada saat akhir pengamatan (saat panen). Dengan cara menghitung jumlah polong yang bernas maupun yang tidak bernas.

\section{Berat polong basah (gr)}

Pengamatan dilakukan pada semua berat polong setiap tanaman sampel dengan menimbang berat polong yang berisi. Pengamatan ini dilakukan pada saat panen.

\section{Jumlah polong cipo (buah)}

Dihitung pada saat sudah panen. Dengan cara menghitung jumlah polong dan dikurangi polong yang bernas.

\section{Berat biji kering (gr)/ tanaman}

Pengamatan ini dilakukan pada saat kadar air $\pm 14 \%$. Untuk mencapai kadar air tersebut dilakukan dengan cara menjemur biji dibawah sinar matahari selama 2-3 hari sampai berat konstan, kemudian ditimbang. Penimbangan biji dilakukan hanya pada tanaman sampel.

\section{Berat 100 biji (gr)}

Pengamatan ini dilakukan dengan cara menimbang 100 biji kedelai, dengan kadar air biji $\pm 14 \%$ yang diperoleh dengan mengeringkan biji di bawah sinar matahari selama 2-3 hari.

\section{HASIL DAN PEMBAHASAN}

\subsection{Hasil}

Hasil analisis keragaman untuk masing-masing faktor dan interaksinya terhadap semua parameter yang diamati yaitu dapat dilihat pada Tabel 3

Tabel 3. Hasil Analisis Keragaman Pada Masukan Energi Jumlah Panas Dan Dosis Pupuk Fosfor Terhadap pertumbuhan dan Hasil Tanaman Kedelai (Glycine max L. Merril).

\begin{tabular}{|c|c|c|c|c|}
\hline \multirow{2}{*}{ Parameter yang diamati } & \multicolumn{3}{|c|}{ F-Hitung } & \multirow{2}{*}{$\mathrm{KK} \%$} \\
\hline & $\mathrm{E}$ & $\mathrm{P}$ & $\mathrm{EP}$ & \\
\hline Tinggi Tanaman & $0.09 \mathrm{~ns}$ & $2.09 \mathrm{~ns}$ & $3.93 \mathrm{~ns}$ & 9.05 \\
\hline Jumlah Daun & $2.18 \mathrm{~ns}$ & $1.25 \mathrm{~ns}$ & $2.88 \mathrm{~ns}$ & 46.23 \\
\hline Jumlah Cabang & $0.30 \mathrm{~ns}$ & $0.19 \mathrm{~ns}$ & $1.95 \mathrm{~ns}$ & 17.89 \\
\hline Berat Basah Tanaman & $12.06 * *$ & $0.62 \mathrm{~ns}$ & $0.75 \mathrm{~ns}$ & 17.83 \\
\hline Berat Kering Tanaman & $3.84^{*}$ & $1.73 \mathrm{~ns}$ & $0.41 \mathrm{~ns}$ & 18.34 \\
\hline Jumlah Polong/tanaman & $2.51 \mathrm{~ns}$ & $1.19 \mathrm{~ns}$ & $0,71 \mathrm{~ns}$ & 6.78 \\
\hline Berat Polong /tanaman & $3.78^{*}$ & $0.15 \mathrm{~ns}$ & $1.07 \mathrm{~ns}$ & 29.60 \\
\hline Jumlah Polong Cipo/tanaman & $2.15 \mathrm{~ns}$ & $1.00 \mathrm{~ns}$ & $0.98 \mathrm{~ns}$ & 33.25 \\
\hline Berat Biji/tanaman & $25,18^{* *}$ & $1,36 \mathrm{~ns}$ & $3,66^{*}$ & 13.99 \\
\hline Berat 100 Biji/tanaman & $0,14 \mathrm{~ns}$ & $0,30 \mathrm{~ns}$ & $0,49 \mathrm{~ns}$ & 10.03 \\
\hline \multicolumn{5}{|c|}{ Keterangan $\quad:$} \\
\hline \multicolumn{5}{|c|}{ : Masukkan Energi Jumlah Panas } \\
\hline \multicolumn{5}{|l|}{ P: Dosis Pupuk Fosfor } \\
\hline \multicolumn{5}{|l|}{ : Interaksi } \\
\hline & \multicolumn{4}{|c|}{ : Berbeda Tidak Nyata } \\
\hline \multicolumn{5}{|l|}{ : Berbeda Nyata } \\
\hline \multicolumn{5}{|l|}{ * * Berbeda Sangat Nyata } \\
\hline KK: Koefisien Keragama & & & & \\
\hline
\end{tabular}


Rata-rata tinggi tanaman pada umur 56bahwa perlakuan masukan energi jumlah Hst dapat dilihat pada Lampiran 3. Analisispanas, dosis pupuk fosfor dan interaksi ragam Lampiran 4 menunjukkan bahwaberbeda tidak nyata terhadap jumlah cabang. perlakuan masukan energi jumlah panas, dosis

pupuk fosfor dan interaksi berpengaruh tidak4.1.4. Berat basah tanaman nyata terhadap tinggi tanaman.

Rata-rata berat basah tanaman dapat

\subsubsection{Jumlah daun (helai)}

dilihat pada Lampiran 10. Analisis

Rata-rata jumlah daun pada umur 56keragaman Lampiran 11 menunjukkan Hst dapat dilihat pada Lampiran 5. Analisisbahwa perlakuan dosis pupuk fosfor dan ragam Lampiran 6 menunjukkan bahwainteraksi berbeda tidak nyata terhadap perlakuan masukan energi jumlah panas, dosisberat basah tanaman, sedangkan pupuk fosfor dan interaksi berbeda tidak nyatamasukan energi jumlah panas berbeda terhadap jumlah daun.

\subsubsection{Jumlah cabang}

berat basah tanaman. Hasil uji DMRT

(Duncan's Multiple Range Test) masukan

Rata-rata jumlah cabang pada umur 56energi jumlah panas dapat dilihat pada Hst dapat dilihat pada Lampiran 7.

Tabel 4.

Table 4. Hasil uji lanjut DMRT berat basah tanaman (gr) pada masukan energi jumlah panas

\begin{tabular}{ll}
\hline Perlakuan & Berat basah tanaman \\
\hline E1 (1030-1050 SP) & $269.41 \mathrm{a}$ \\
E2 $(1130-1150 \mathrm{SP})$ & $286.67 \mathrm{a}$ \\
E3 $(1230-1250 \mathrm{SP})$ & $278.15 \mathrm{a}$ \\
E4 (1330-1350 SP) & $179.85 \mathrm{~b}$ \\
\hline
\end{tabular}

Keterangan : Angka-angka yang diikuti oleh huruf pada kolom yang sama berbeda tidak nyata dengan uji DMRT pada taraf $5 \%$

Berdasarkan hasil uji lanjut DMRT (Duncan's Multiple Range Test) masukan energi jumlah panas perlakuan E1 (1030-1050 SP) berbeda tidak nyata dengan E2 (1130-1150 SP) dan E3(1230-1250 SP) tetapi berbeda nyata dengan E4 (1230-1250 SP).

4.1.5. Berat kering tanaman (gr) Rata-rata berat kering tanaman dapat dilihat pada lampiran 12. Analisis 
keragaman Lampiran 13 menunjukkan bahwa perlakuan dosis pupuk fosfor dan interaksi berbeda tidak nyata terhadap berat kering tanaman, sedangkan masukan energi jumlah panas menunjukkan pengaruh berbeda nyata terhadap berat kering tanaman. Hasil uji DMRT (Duncan's Multiple Range Test) Masukan Energi Jumlah Panas dan Dosis Pupuk Fosfor dapat dilihat pada Tabel 5. 
Tabel 5. Hasil uji lanjut DMRT berat kering tanaman (gr) pada masukan energi jumlah panas

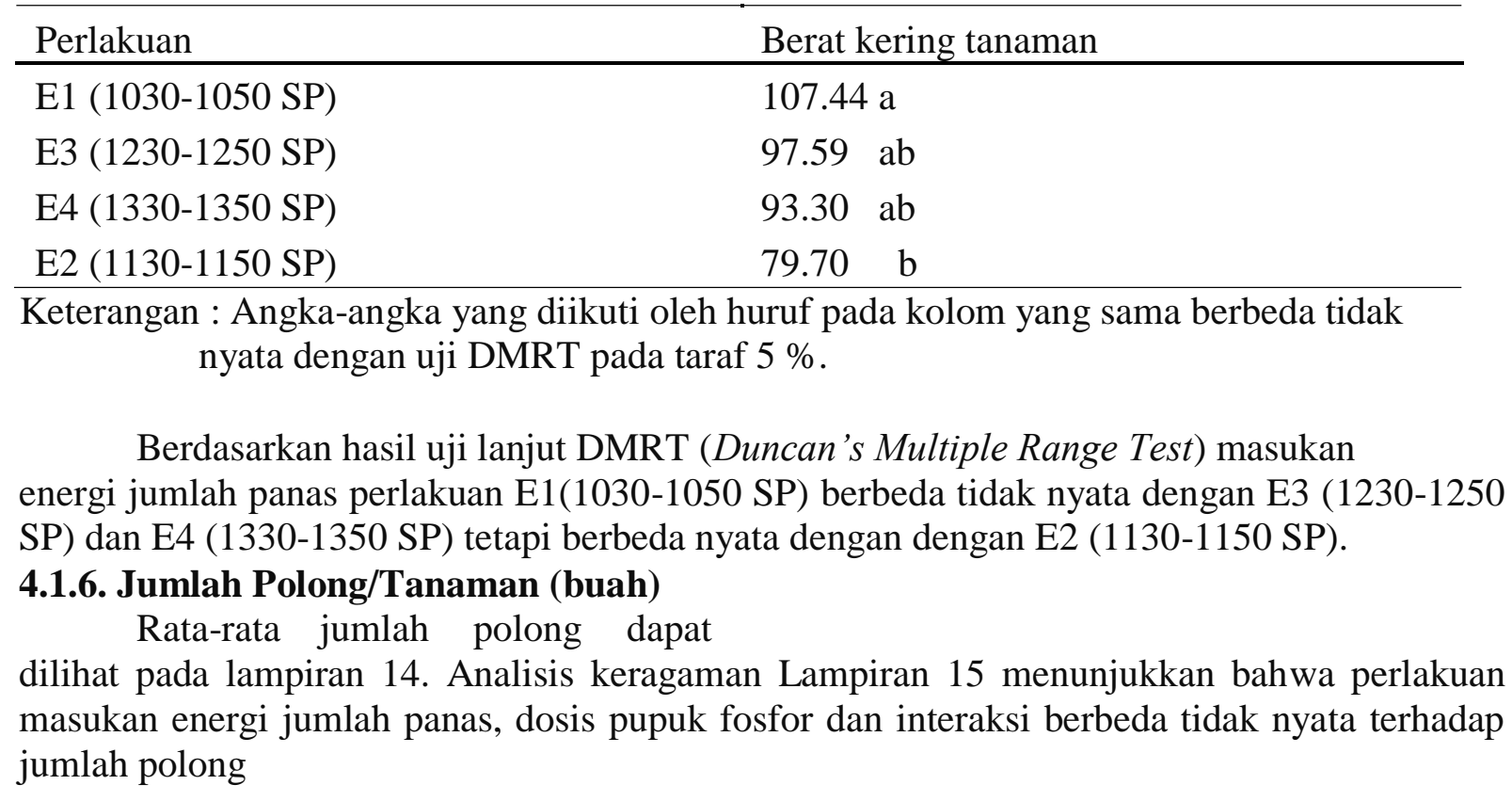


4.1.7. Berat polong/tanaman (gr) Rata-rata berat polong dapat dilihat pada lampiran 16. Analisis keragaman Lampiran 17 menunjukkan bahwa perlakuan dosis pupuk fosfor dan interaksi berpengaruh berbeda tidak nyata, sedangkan masukan energi jumlah panas menunjukkan pengaruh berbeda sangat nyata, seperti yang terlihat pada Lampiran

27. Hasil uji DMRT (Duncan's Multiple

Range Test) Masukan Energi Jumlah Panas dan Dosis Pupuk Fosfor dapat dilihat pada Tabel 6.

Tabel 6. Hasil uji lanjut DMRT berat polong (gr) pada masukan energi jumlah panas

\begin{tabular}{ll}
\hline Perlakuan & Berat polong (gr) \\
\hline E3 (1230-1250 SP) & $137.26 \mathrm{a}$ \\
E2 (1130-1150 SP) & $107.44 \mathrm{ab}$ \\
E4 (1330-1350 SP) & $95.74 \quad \mathrm{~b}$ \\
E1 (1030-1050 SP) & $91.30 \quad \mathrm{~b}$ \\
\hline
\end{tabular}

Keterangan : Angka-angka yang diikuti oleh huruf pada kolom yang sama berbeda tidak nyata dengan uji DMRT pada taraf $5 \%$.

Berdasarkan hasil uji lanjut DMRT dengan E4 (1330-1350 SP) dan E1 (1030-

(Duncan's Multiple Range Test) masukan 1050 SP).

energi jumlah panas perlakuan E3 (1230- 4.1.8. Jumlah polong cipo/tanaman

$1250 \mathrm{SP}$ ) berbeda tidak nyata dengan E2 (buah)

(1130-1150 SP) tetapi berbeda nyata Rata-rata jumlah polong dapat dilihat pada lampiran $18 . \quad$ Analisis 
keragaman Lampiran 19 menunjukkan bahwaperlakuan masukan energi jumlah panas dan perlakuan masukan energi jumlah panas, dosisinteraksi berbeda sangat nyata dan berbeda pupuk fosfor dan interaksi berbeda tidak nyatanyata terhadap berat biji, sedangkan dosis terhadap jumlah polong.

pupuk fosfor menunjukkan pengaruh

4.1.9. Berat biji/tanaman (gr) berbeda tidak nyata terhadap berat biji. Hasil

Rata-rata berat biji dapat dilihat padauji DMRT (Duncan's Multiple Range

lampiran 20. Analisis keragaman Test) Masukan Energi Jumlah Panas dan

Lampiran 21 menunjukkan bahwa Interaksi dapat dilihat pada Tabel 7 dan 8.

Table 7. Hasil uji lanjut DMRT berat biji (gr) pada masukan energi jumlah panas.

\begin{tabular}{ll}
\hline Perlakuan & Berat biji (gr) \\
\hline E3 (1230-1250 SP) & $35.44 \mathrm{a}$ \\
E2 (1130-1150 SP) & $25.97 \quad$ b \\
E4 (1330-1350 SP) & $23.31 \quad$ bc \\
E1 (1030-1050 SP) & $21.47 \quad \mathrm{c}$ \\
\hline
\end{tabular}

Keterangan : Angka-angka yang diikuti oleh huruf pada kolom yang sama berbeda tidak nyata dengan uji DMRT pada taraf $5 \%$.

Berdasarkan hasil uji lanjut DMRT (1330-1350 SP) dan E1 (1030-1050 SP).

(Duncan's Multiple Range Test) masukan Perlakaun E2 (1130-1150 SP) berbeda tidak energi jumlah panas menunjukkan nyata dengan E4 (1330-1350 SP) tetapi

perlakuan E3 (1230-1250 SP) berbeda berbeda sangat nyata dengan E1 (1030sangat nyata dengan E2 (1130-1150 SP), E4 1050 SP).

Tabel 8. Hasil uji lanjut Interaksi berat biji (gr) pada masukan energi jumlah panas dan dosis pupuk fosfor.

\begin{tabular}{ccc}
\hline Perlakuan & Rata-rata & Huruf \\
\hline E4P1 & 17.77 & $\mathrm{a}$ \\
E1P2 & 19.22 & $\mathrm{a}$ \\
E2P3 & 22.11 & $\mathrm{a}$ \\
E1P1 & 22.22 & $\mathrm{a}$ \\
E1P3 & 22.99 & $\mathrm{a}$ \\
E4P3 & 24.77 & $\mathrm{ab}$ \\
E4P2 & 27.33 & $\mathrm{~b}$ \\
E2P1 & 27.66 & $\mathrm{~b}$ \\
E2P2 & 28.11 & $\mathrm{bc}$ \\
E3P1 & 32.88 & $\mathrm{c}$ \\
E3P2 & 33.22 & $\mathrm{c}$ \\
E3P3 & 40.22 & $\mathrm{~d}$ \\
\hline
\end{tabular}

Keterangan : Angka-angka yang diikuti oleh huruf pada kolom yang sama berbeda tidak nyata dengan uji DMRT pada taraf $5 \%$. 
Berdasarkan hasil uji lanjut DMRT (Duncan's Multiple Range Test) interaksi

perlakuan masukan energi jumlah panas dan dosis pupuk fosfor menunjukan pelakuan E4P1 berbeda tidak nyata dengan E1P2, E2P3, E1P1, E1P3, E4P3 tetapi berbeda nyata dengan E4P2, E2P1, E2P2, E3P1, E3P2 dan E3P3. Pelakuan E1P2 berbeda tidak nyata dengan E2P3, E1P1, E1P3, E4P3 tetapi berbeda nyata dengan E4P2, E2P1, E2P2, E3P1, E3P2 dan E3P3. Pelakuan E2P3 berbeda tidak nyata dengan E1P1, E1P3, E4P3 tetapi berbeda nyata E2P1 berbeda tidak nyata dengan E2P2 tetapi berbeda nyata dengan E3P1, E3P2 dan E3P3. Pelakuan E2P2 berbeda tidak nyata dengan E3P1, E3P2 tetapi berbeda

nyata dengan E3P3. Pelakuan E3P1 berbeda tidak nyata dengan E3P2 tetapi berbeda nyata dengan E3P3. Pelakuan E3P2 berbeda nyata dengan E3P3.

4.1.10. Berat 100 biji/tanaman (gr) Rata-rata berat 100 biji dapat dilihat pada lampiran 22 .

Analisis keragaman

Lampiran 23 menunjukkan bahwa perlakuan masukan energi jumlah panas, dosis pupuk fosfor dan interaksi berbeda tidak nyata terhadap berat 100 biji.

\subsection{PEMBAHASAN}

perlakuan berbeda nyata terhadap berat biji.

Pada pengamatan berat basah tanaman Lampiran 11 analisis keragaman menunjukkan perlakuan masukan energi jumlah E1 berbeda sangat nyata demgan E4 bahwa hal ini diduga pada perlakuan E1 masih mengalami proses fotesintesis sehingga terjadi peningkatan berat basah

tanaman. Bahwa hal ini sependapat

dengan Sudjadi (2005) terjadinya peningkatan berat segar disebabkan oleh lajunya fotosintesis, dimana cahaya mempunyai peran yang sangat penting terhadap proses fotosintesis. 
dengan E4P2, E2P1, E2P2, E3P1, E3P2 dan E3P3. Pelakuan E1P1 berbeda tidak nyata dengan E1P3, E4P3 tetapi berbeda nyata dengan E4P2, E2P1, E2P2, E3P1, E3P2 dan E3P3. Pelakuan E1P3 berbeda tidak nyata dengan E4P3 tetapi berbeda nyata dengan E4P2, E2P1, E2P2, E3P1, E3P2 dan E3P3. Pelakuan E4P3 berbeda tidak nyata dengan E4P2, E2P1, E2P2 tetapi berbeda nyata dengan E3P1, E3P2 dan E3P3. Pelakuan E4P2 berbeda tidak nyata dengan E2P1, E2P2 tetapi berbeda nyata dengan E3P1,

E3P2 dan E3P3. Pelakua

Data hasil analisis ragam menunjukkan bahwa perlakuan Masukan Energi Jumlah Panas (MEJP) berbeda sangat nyata terhadap berat basah tanaman, berat polong, berat biji dan berat kering tanaman, tetapi berbeda tidak nyata terhadap tinggi tanaman, jumlah daun, jumlah cabang, jumlah polong, jumlah polong cipo dan berat 100 biji. Perlakuan dosis pupuk fosfor berbeda tidak nyata terhadap tinggi tanaman, jumlah daun, jumlah cabnag, berat basah tanaman, berat kering tanaman, jumlah polong, berat polong tanaman, jumlah polong cipo, berat biji, berat 100 biji dan interaksi kedua

Pada pengamatan berat kering tanaman Lampiran 13 analisis keragaman menunjukkan perlakuan masukan energi jumlah E1 berbeda nyata dengan E2 bahwa hal ini diduga penyerapan intensitas cahaya yang makin tinggi dapat menghasilkan bahan kering yang tinggi. Bahwa hal ini sependapat dengan Heddy (2002) intensitas cahaya matahari yang optimal akan berpengaruh positif terhadap proses fotosintesis yang pada akhirnya akan menghasilkan bahan kering tanaman yang tinggi. Selain itu, menurut Yulisma (2011) tinggi rendahnya bobot kering tanaman ditentukan oleh laju fotosistesis yang 
merupakan penimbunan fotosintat selama pertumbuhan.

Pada pengamatan berat polong

Lampiran 17 analisis keragaman menunjukkan perlakuan masukan energi jumlah panas E3 berbeda nyata dengan E4 dan E1 bahwa hal ini di duga adanya keragaman suhu harian, hal ini sesuan dengan pendapat Polli (1996) dikutip Pratama (2013) menyatakan bahwa adanya keragaman suhu harian dapat memberikan hasil yang tidak selalu sama berdasarkan satuan hari.

Pada pengamatan berat biji Lampiran 21 analisis keragaman perlakuan masukan energi jumlah E3 berbeda sangat nyata dengan E2, E4 dan E1 bahwa hal ini diduga hasil dari proses fotosintesis banyak ditranferkan pada proses pengisian biji. Bahwa hal ini sependapat dengan Indriati (2009), fosfor berperan dalam pembentukan biji, mempercepat pembentukan bunga serta masaknya buah dan biji, meningkatkan rendemen dan komponen hasil panen tanaman biji-bijian. Unsur fosfor berperan dalam meningkatkan pengisian biji tanaman kedelai sehingga dengan pemberian fosfor yang tinggi akan meningkatkan berat biji

tanaman kedelai. Nelza (2016) juga menyebutkan bahwa meningkatnya intensitas cahaya matahari akan berpengaruh positif terhadap perkembangan polong dan biji, hal ini dikarenakan fotosintat yang dihasilkan akan ditransfer pada proses pengisian biji sehingga ukuran biji dan jumlahnya akan maksimal.

Hasil analisis keragaman menunjukan bahwa masukan energi jumlah panas dan dosis pupuk fosfor berbengaruh tidak nyata terhadap tinggi tanaman, jumlah daun, jumlah cabang, jumlah polong, jumlah polong cipo dan berat 100 biji. Menurut Tarigan (2009), bahwa tanaman akan tumbuh dan menghasilkan secara optimal apabila ditanam di tempat yang 
memenuhi syarat tumbuhnya seperti faktor lingkungan yaitu faktor iklim seperti sifat tanah dan ketersediaan unsur hara. Selain itu Widiastuti dan Evi (2016) melaporkan adanya peningkatan aktivitas fotosintesis akan meningkatkan jumlah karbohidrat yang dihasilkan sebagai cadangan makanan

dalam bentuk polong, sehingga terakumulasinya hasil fotosintat dari karbohidrat ke cadangan makanan dalam bentuk biji akan bertambah.

\section{KESIMPULAN DAN SARAN 5.1. Kesimpulan}

Berdasarkan hasil analisis dan pembahasan tentang pengaruh masukan energi jumlah

panas (MEJP) dan dosis pupuk fosfor terhadap pertumbuhan dan hasil tanaman kedelai (Glycine max L. Merril) dapat disimpulkan bahwa:

1. Perlakuan masukan energi jumlah panas berpengaruh sangat nyata terhadap berat basah tanaman dan berat biji/tanaman, berat kering tanaman dan berat polong /tanaman. Perlakuan masukan energi jumlah panas yang terbaik pada taraf MEJP (1230-2050 SP).

2. Perlakuan dosis pupuk fosfor berpengaruh tidak nyata.

3. Adanya interaksi antar masukan energi jumlah panas dan dosis pupuk fosfor pada berat biji.

\subsection{Saran}

Pada penelitian hasil analisis dan pembahasan tentang pengaruh masukan energi jumlah panas (MEJP) dan dosis pupuk fosfor terhadap pertumbuhan dan hasil tanaman kedelai (Glycine max L. Merril) disarankan untuk melakukan sebagai berikut:

1. Perlu dilakukan penelitian lebih lanjut tentang daya perkecambahan kedelai benih (Glycine max L. Merril) hasil penelitian . 
2. Pengaplikasian pupuk fosfor sebaiknya menggunakan dosis $75 \mathrm{~kg} / \mathrm{ha}$ dilakukan 2 kali dalam satu periode tanam.

\section{DAFTAR PUSTAKA}

Adisarwanto. 2005. Budidaya Kedelai dengan Pemupukan yang Epektif dan Pengoptimalan Peran Bintil Akar. Penebar Swadaya . Jakarta.

. 2005. Meningkatkan Hasil Panen Kedelai di Lahan Sawah Kering Pasang Surut. Penerbit Swadaya.

. 2008. Budidaya Kedelai Tropika. Penebar swadaya. Jakarta.

- 2014. Budidaya Kedelai Tropika Produktifitas 3 ton/ha. Penebar swadaya . Jakarta.

Aksi Agraris Kanisius. 2000. Kacang tanah. Penerbit Kanisius. Yokyakarta

Amilia, Y. 2011. Penggunaan Pupuk Organic Cair untuk Mengurangi Dosis Penggunaan Pupuk Anorganik pada Pai Sawah (Oryza sativa L). Skripsi S1 Fakultas Pertanian Institute Pertanian Bogor. Bogor. $47 \mathrm{hlm}$.

Andrianto, T. T., dan N. Indarto., 2004. Budidaya dan Analisis Usaha Tani Kedelai, Kacang Hijau, Kacanng Panjang. Absolut, Yogyakarta

Astuty, Mery, Setyastuti P., Dody K., Tri

H., Purwidyanto, Sony N. 2012.

Petunjuk Praktis Kedelai Hitam.

Penerbit: Penebar Swadaya.

Atman, 2014. Strategi Meningkatkan Produksi Kedelai Melalui PTT. Graha Ilmu. Yokyakarta.

BPS (Badan Pusat Penelitian), 2017. Tabel Luas Panen-Produktivitas-Produksi Tanaman Kedelai Seluruh Provingsi Bengkulu.

Cahyono, B. 2007. Kedelai (Teknik Budidaya dan Analisis Usaha Tani). Aneka Ilmu, Semarang. 153 hlm. 
Dwi. 2011. dalam jurnal pengaruh media tanam terhadap tanaman kedelai. Jakarta. Efendi. 2010. Peningkatan pertumbuhan dan produksi kedelai melalui kombinasi pupuk organic lamtorogung dengan pupuk kandang J Floratek 5: 65-122.

Farmanta, Y., Yartiwi dan Yulie Oktavia. 2013. Test Power Of Soybean In Bengkulu. Balai Pengkajian

Teknologi Pertanian (BPTP)

Bengkulu. Bengkulu. Email : bptp@bengkulu.deptan.go.id

Fasokha Nurbaiti, Gembong Haryono, Agus

Suprapto. 2017. Pengaruh Pemberian Mulsa dan Jarak Tanam pada Haasil Tanaman Kedelai (Glycine max L. Merril) Var. Grobongan. Jurnal Ilmu Pertanian Tropika dan Subtropika 2(2) : $41-47$.

Fredi kurniawan. 2015. Klasifikasi dan morfologi kedelai. http://fredikurniawan.com/klasifikas i-dan-morfologi-kacangkedelai. Diakses 9 maret 2016.

Heddy S. 2002. Ekofisiologi tanaman, suatu kajian kuantitatif pertumbuhan tanaman. Divisi Buku Perguruan Tinggi. Jakarta (Indones); PT Raja Grafindo Persada

Irwan, W.A. 2006. Budidaya Tanaman Kedelai (Glycine max (L.) Merill). Universitas Padjajaran: Jatinangor

Muh, S.2010. tanaman kedelai (glycine max. L) http://deskripsitanaman.blogspot.co. id/2010/01/tanaman-kedelai-glycinemax-1.html. Diakses tanggal 4 april 2016.

Nelza, A. 2016. Studi fenologi, karakter hasil dan mutu benih tanaman kacang koro pedang (Canavalia ensiformis L.) pada perbedaan 
kondisi naungan dan pemupukan. Tesis. Institut Pertanian Bogor. Bogor

Pratama, Dorizky, 2013. Masukan Jumlah Energi Panas dan Macam-macam Bioaktivator Darah Sapi Terhadap Pertumbuhan dan Hasil Kacang Kedelai (Glycine max L. Merril). Bengkulu.

Purwono dan Heni Purnawati 2007. Budidaya 8 Jenis Tanaman Pangan Unggul. Penebar Swadya. Jakarta.

Sarawa, Nurmas A, Aj MD. 2012. Pertumbuhan dan produksi tanaman kedelai Glycine max L. (Merril) dengan pemberian pupuk organik cair. Agroekoteknologi 2 (2): 653-661.

Sattar A, Iqbal M, Areeb A, Ahmad Z, Irfan M, Shabbir M, Aisim G, Hussain S. 2015. Genotypic variations in wheat for phenologi and accumulative heat unit under different sowing times. $J$ Environ Agric Sc. 2(8): 18.

Simanjuntak D. (2005). Peranan Trichoderma, Micoriza dan Posfat terhadap Tanaman Kedelai pada

Tanah Sangat Masam (Humitropets). J. Penelitian Bidang Ilmu Pertanian, 3 (1), 3642.

Sudjadi 2005. Pengaturan cahaya lampu sebagai fotosintesis phytoplankton buatan dengan menggunakan mikrokontroler At89s52. [diakses pada 1 Juni 2005]. http://www.emakpancarsakti.com..

Sulistyowati TE, Purnomo D, Pujiasmanto B. 2015. Pengaruh Umur Panen terhadap hasil dan kualitas benih tiga varietas kedelai (Glycine max (L.) Merril). Jurnal El-Vivo 3 (2): 2233. 
Susanto, dan T. Sundari, 2011. Perubahan karakter agronomi aksesi plasma nutfah kedelai di lingkungan

ternaungi. Jurnal Agronomi Indonesia, 39(1): 1-6

Sutedjo, M.M., 2002. Pupuk dan Cara Pemupukan. Rineka Cipta. Jakarta. Hal 20-21

Syahni, R. dan Nelly, $\quad$ N. 2017. Analisis

Statistik Untuk Penelitian

Pertanian. Andalas University Press. Padang. 321.

Tarigan, K. 2009. Pengaruh pupuk terhadap Optimasi Produksi Tanaman. Universitas Sumatra Utara, Medan.

Perdana Lea Jansen, Rasyad Aslim, Zuhry Elza. 2012. Pengaruh Beberapa Dosis Fosfor (P) Terhadap Mutu Benih Berbagai Kultivar Kedelai (Glycine max L. Merril) Selama Pengisian Dan Pemasakan Biji. Fakultas Pertanian Riau. Riau. 12 hlm.

Podesta. 1997. Masukan Energi Jumlah Panas dan Konsentrasi 2,4-D Terhadap Hasil, Mutu Benih dan Kualitas Gizi Kedelai (Glycine max L. Merril). PROGRAM Pacsa

Sarjana. Universitas Andalas.

Padang.

Vivi. 2011. Teknik budidaya tanaman

kedelai.

http://chiliholicz.blogspot.co.id/2011

/09/teknik-budidaya-tanaman

kedelai.html. Diakses tanggal 4 april

2016.

Widianstuti, L., Tohari dan S. Endang. 2004. Pengaruh Intesitas Cahaya dan Kadar Daminosida Terhadap Iklim Mikro dan Pertumbuhan Tanaman Krisan Dalam Pot. J. Ilmu Pertanian. 11(2): 35-42.

Widiastuti E, Evi L. (2016). Keragaan Pertumbuhan dan Biomassa Varietas 
Kedelai (Glycine max $(L)$ ) di Lahan Sawah dengan Aplikasi Pupuk Organik Cair. Jurnal Ilmu Prtanian Indonesia, 21 (2), 90-97.

Winarni, I., E.S. Sumadiwangsa dan D. Setyawan. 2004. Pengaruh Tempat Tumbuh, Jenis dan Diameter Batang Terhadap Produktivitas Pohon Penghasil Biji Tengkawang. J. Penelitian Hasil Hutan. 22(1): 23-33 Yulisma. 2011. Pertumbuhan dan Hasil beberapa Varietas Jagung pada Berbagai Jarak Tanam. PenelitianPertanian Tanaman Pangan 30(3): 196-203.

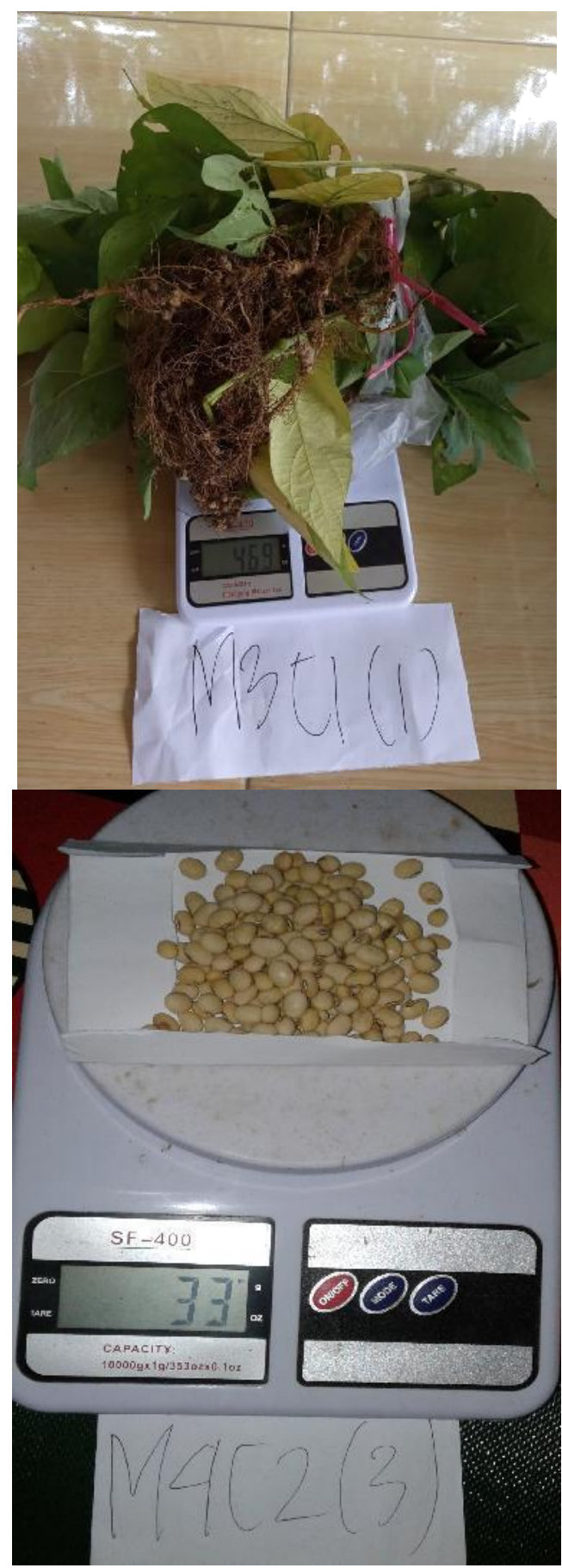

